\title{
ESTIMATION OF GROUND SNOW LOAD USING SNOW LAYER MODEL
}

\author{
積雪層モデルによる地上積雪荷重の推定
}

\author{
Toru TAKAHASHI*, Taiki KAWAMURA** and Koji KURAMOTO*** \\ 高橋＼cjkstart徹，川村大樹，倉本幸 治
}

\begin{abstract}
For useful estimation of ground snow load, the authors have built the snow layer model using data of daily precipitation, daily mean and daily minimum air temperature. Although the catch ratio of solid precipitation is important for estimating the snow load on the ground, the calculation results using the catch ratio proposed by Ohno et al. was not sufficient for some observation points. Therefore the authors proposed the new equation for the catch ratio using daily mean temperature. The results with newly proposed catch ratio was sufficient for every observation points.
\end{abstract}

Keywords: Snow load, Snow layer, Precipitation, Daily mean air temperature, Catch ratio of precipitation gauge 積雪荷重, 積雪層, 降水量, 日平均気温, 降水量計の捕捉率

\section{INTRODUCTION}

In Japan, there are few stations at which snow weight on the ground is measured directly. To obtain snow weight, we normally use snow depth data and multiply them by an equivalent snow density. However, there are many automatic observation stations that observe precipitation. Therefore, it is necessary to estimate snow weight from precipitation data. Kamimura et al. ${ }^{17}$ estimated daily snow mass on the ground using precipitation data for road snow removal. Sakurai et al. ${ }^{2)}$ also estimated ground snow load. However, for estimating annual maximum snow load, it is important to define the melting process and it's the melting quantity. The authors have developed a snow layer model for estimating ground snow depth and snow weight. Both estimated data are compared with real observed data to verify the validity of the model.

\section{DEVELOPMENT OF SNOW LAYER MODEL}

\subsection{Snow layer}

It is well known that snow on the ground is made up of layers comprising one layer for each snowfall. In this study, it was assumed that each day's snowfall formed one layer. After a snowfall, the snow consolidates and metamorphoses in proportion to the number of days and the tempera- ture. Finally, it melts and it is assumed to percolate into the ground. These processes are constituted by snow density and a snowmelt coefficient, as shown in Figures 1 and 2. They are defined as follows.

\subsection{Snow Density}

During a snowfall at low temperature, snow with low density falls. When the temperature is high, the density varies. ${ }^{3)}$ The authors defined the density of snow during a snowfall as shown in Figure 1a, based on engineering judgement. This is described as follows:

$$
\begin{array}{rlrl}
{ }_{m} \rho_{0} & =\rho_{\min } & & \left(T \leq 0^{\circ} \mathrm{C}\right) \\
{ }_{m} \rho_{0}=\rho_{\min }+\frac{\rho_{\max }-\rho_{\min }}{3}{ }_{m} T & & \left(0^{\circ} \mathrm{C}<T \leq 3^{\circ} \mathrm{C}\right) \\
{ }_{m} \rho_{0}=500\left[\mathrm{~kg} / \mathrm{m}^{3}\right] & & \left(3^{\circ} \mathrm{C}<T\right)
\end{array}
$$

where, $m=$ number of days from the start of continuous snow cover, ${ }_{m} \rho_{0}$ $=$ density of a snowfall on the $m$ th day from the start of continuous snow cover, $\rho_{\min }=$ minimum density of snowfall as calculated in the following section and it is fixed in a winter, $\rho_{\max }=$ maximum density of snowfall fixed as $500 \mathrm{~kg} / \mathrm{m}^{3}$ considering metamorphosis of snow, and ${ }_{m} T=$ daily mean air temperature of the corresponding day. The snow density of the snowfall is fixed as $500 \mathrm{~kg} / \mathrm{m}^{3}$ when ${ }_{m} T$ is warmer than $3^{\circ} \mathrm{C}$, but the snowfall might melt as described in section 2.4 .

\footnotetext{
本論文の一部は日本建築学会大会等4,5, (6),7)で発表した。また本論文の内容は第 4 回雪工学国際会議で口頭発表した。

* Assoc. Prof., Faculty of Engineering, Chiba University, Dr. Eng. 千葉大学工学部 助教授・工博

** TIS \& Partners, M. Eng.

ティアイエスエンドパートナーズ 修士(工学)
川崎製鉄㑣) 修士(工学)

*** Kawasaki Steel Corporation, M. Eng.
} 


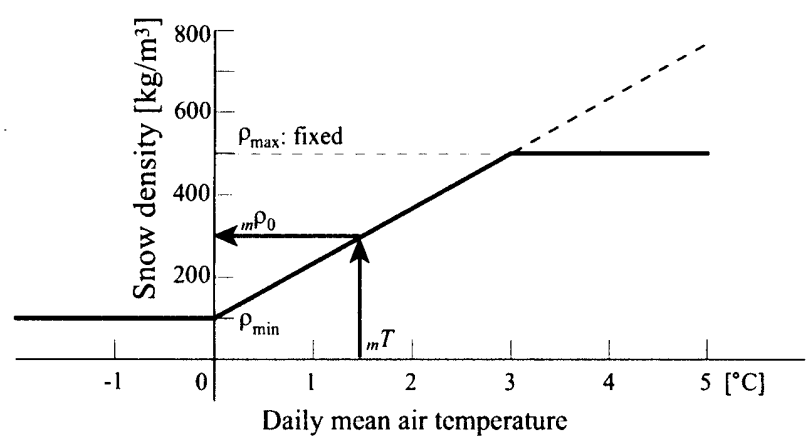

(a) Snow density at snowfall

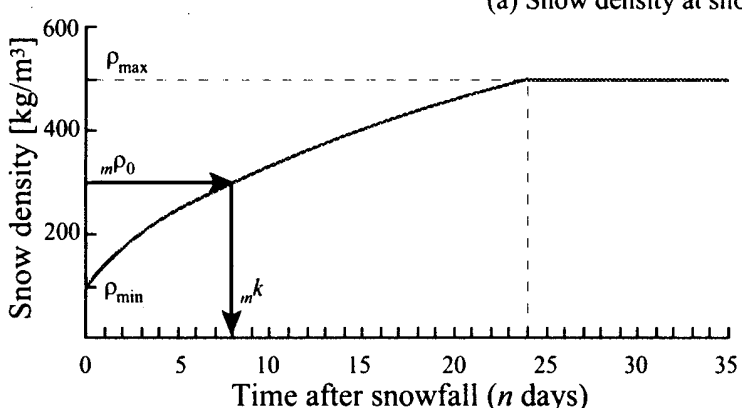

(b) Snow density after snowfall

Figure 1. Model of snow density at and after the snowfall. (Example for $\rho_{\min }=100 \mathrm{~kg} / \mathrm{m}^{3}$ )

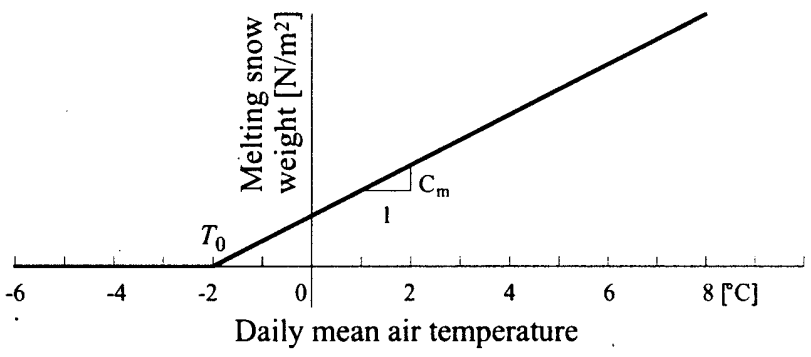

Figure 2. Model of daily meiting snow weight.

After the snowfall, snow is consolidated day after day. An empirical value for the density and thickness of a layer has been expressed as follows ${ }^{8)}$ :

$$
\begin{aligned}
& { }_{m} \rho_{n}=\rho_{\min } \sqrt{n} \\
& { }_{m} d_{n}=\frac{{ }_{m} r}{\rho_{\min } \sqrt{n}}
\end{aligned}
$$

where, $n=$ number of days from the snowfall of the layer, and ${ }_{m} r=$ precipitation of the corresponding snowfall. The authors considered the initial condition of snowfall and improved this process as follows:

$$
\begin{aligned}
& { }_{m} \rho_{n}=\rho_{\min } \sqrt{n+{ }_{m} k} \\
& { }_{m} d_{n}=\frac{{ }_{m}^{r}}{\rho_{\min } \sqrt{n+{ }_{m} k}}
\end{aligned}
$$

where, ${ }_{m} k=$ the correction number for the initial condition. ${ }_{m} k$ is obtained when $n$ is put in Equation 4 with 0, as follows:

$$
{ }_{m} k=\frac{\left({ }_{m} \rho_{i}\right)^{2}}{\rho_{\min }^{2}}
$$

This means that snowfall and consolidation starts from ${ }_{m} k$ days in Figure lb. The density of the layer does not change when the consolidation

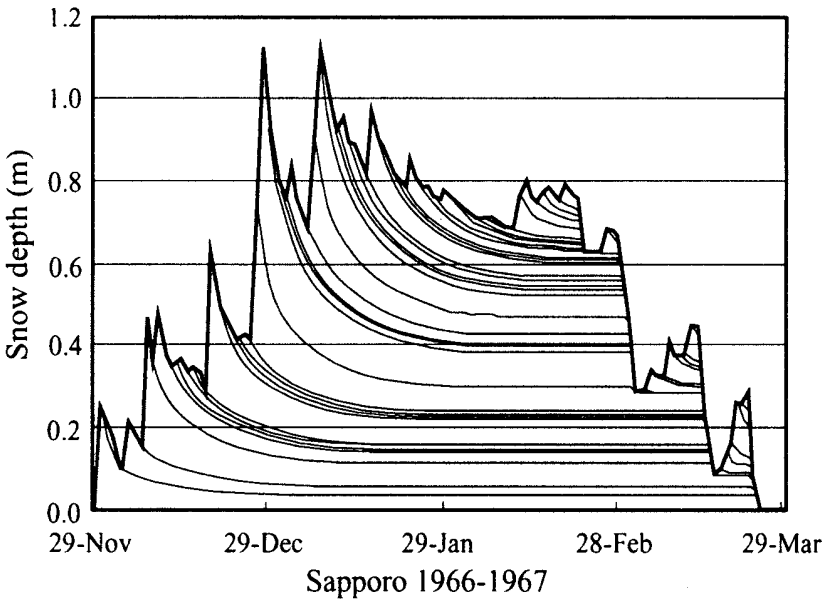

Figure 3. Example of transition process of snow layers.

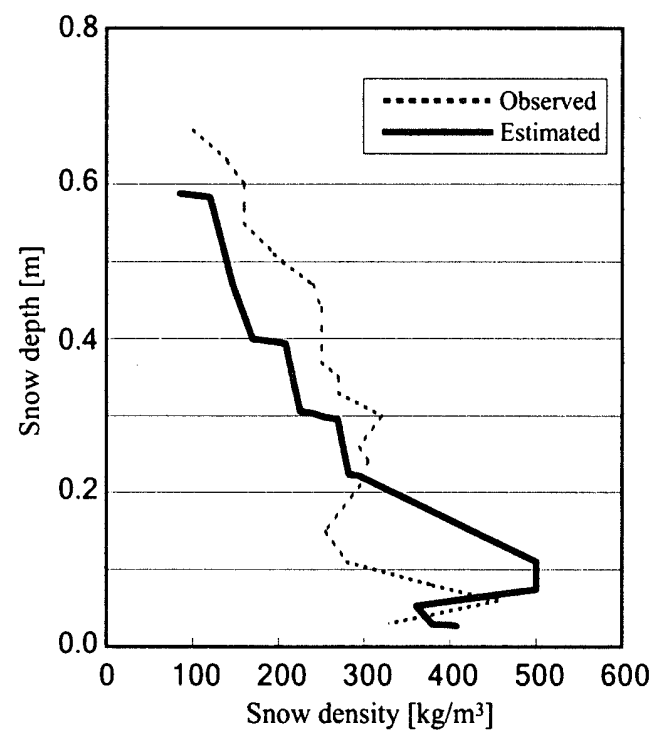

Figure 4. Example of snow pit observation and corresponding estimated results. (Sapporo, February 4, 1964)

progresses to $500 \mathrm{~kg} / \mathrm{m}^{3}$. An example of the transition process of snow layers in snow depth and elevation of snow density of this model are shown in Figure 3 and Figure 4, respectively.

\subsection{Discrimination between rain and snow}

When the daily minimum air temperature was warmer than $2^{\circ} \mathrm{C}$, the precipitation of the day was judged as rain $^{8)}$, and all of the water was considered to have moved into lower layer, until the corresponding layer's density reaches to $500 \mathrm{~kg} / \mathrm{m}^{3}$. When the calculated density of the layer exceed $\rho_{\max }$, the superfluous part moves into the next layer. Finally, the superfluous part that can not stay any layers percolates into the ground. This means that the snow layer model can consider rain load in the middle of winter season.

\subsection{Snowmelt coefficient}

A number of studies have been carried out to consider the mechanism of snow melt (for example, Yoshida ${ }^{9)}$, Otoishi ${ }^{101}$ ). In the present paper, the authors have assumed that the snowmelt quantity is proportional to the daily mean air temperature, as shown in Figure 2. Daily melting snow weight $W_{C}$ is expressed as follows:

$$
W_{C}=C_{m}\left(T-T_{0}\right) \quad\left(T_{0}<T\right)
$$




$$
W_{c}=0
$$$$
\left(T \leq T_{0}\right)
$$

where, $C_{m}=$ snowmelt coefficient calculated in the analysis and assumed to be constant for one winter season, $T=$ daily mean air temperature of the calculating day, and $T_{0}=$ reference temperature for snowmelt. Snowmelt occurs when $T$ is warmer than $T_{0}$. In the present paper, $T_{0}$ is fixed at $-2^{\circ} \mathrm{C}$. Snow fundamentally melts when the temperature is higher than $0^{\circ} \mathrm{C}$. However, the reference temperature was set to be the $-2^{\circ} \mathrm{C}$. This value was chosen because the temperature may sometimes exceed $0^{\circ} \mathrm{C}$ during the daytime, even though the daily mean air temperature is negative. The melted water of volume $W_{C}$ moves as the same as described in section 2.3 .

\subsection{Catch ratio of gauges}

Precipitation is measured with precipitation gauges. In Japan, three types of gauges are conventionally used by the Japan Meteorological Agency. Ohno et al. ${ }^{11)}$ reported that in the Hokuriku region, the catch

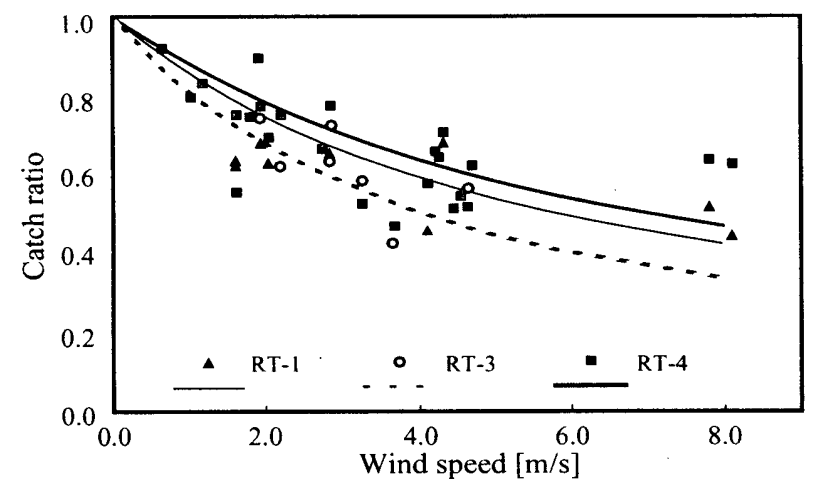

Figure 5. Relationship between catch ratio and wind speed. (By Ohno et al. ${ }^{11}$ )

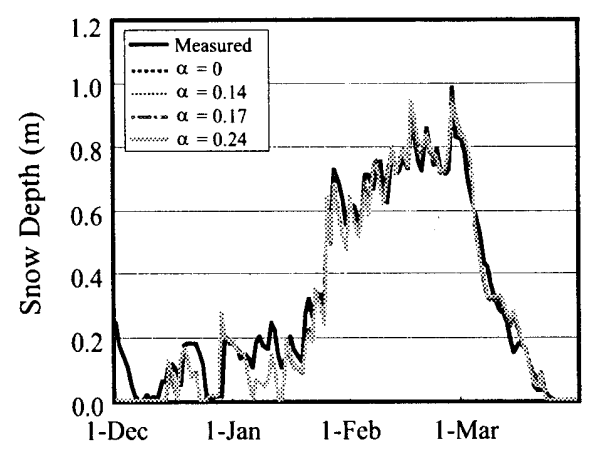

a) Sapporo $1963-1964$

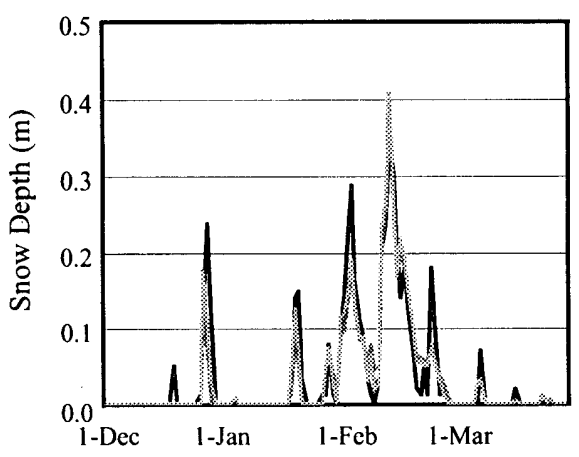

d) Toyama 1963-1964

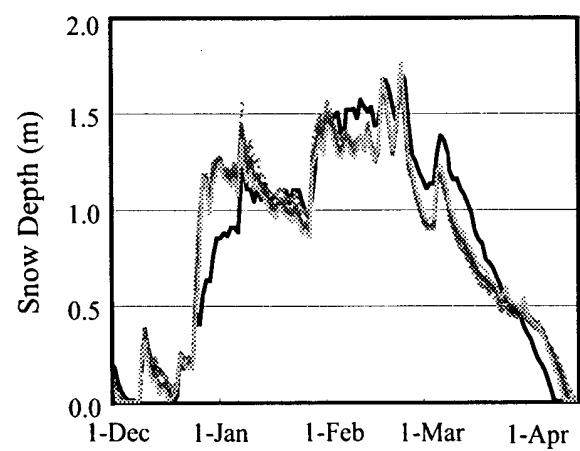

b) Shinjo 1976-1977

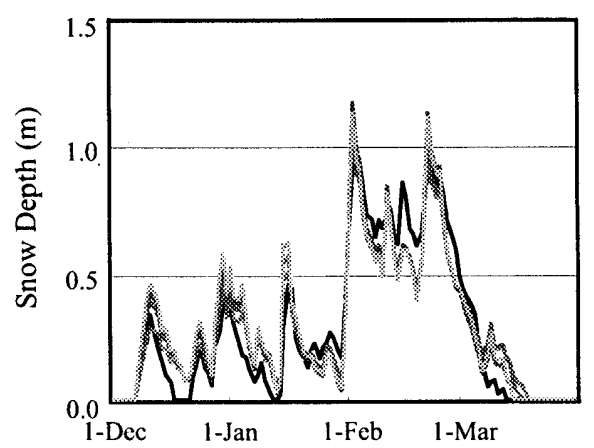

e) Toyama 1967-1968

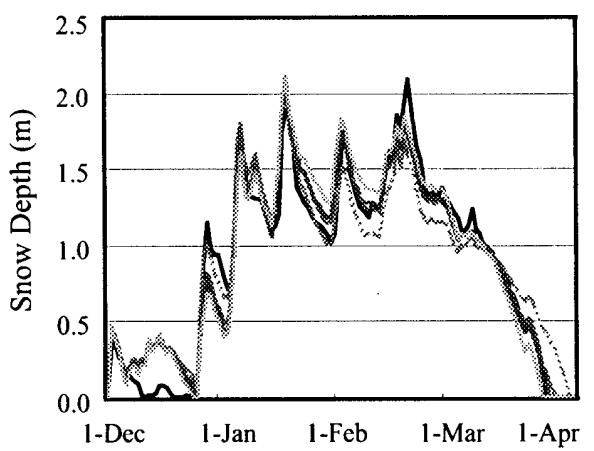

c) Takada $1966-1967$

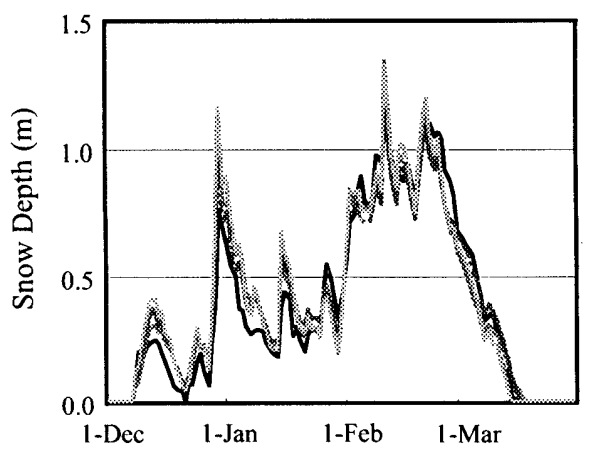

f) Fukui $1967-1968$

Figure 6. Example of measured and estimated snow depth using Ohno's catch ratio. 


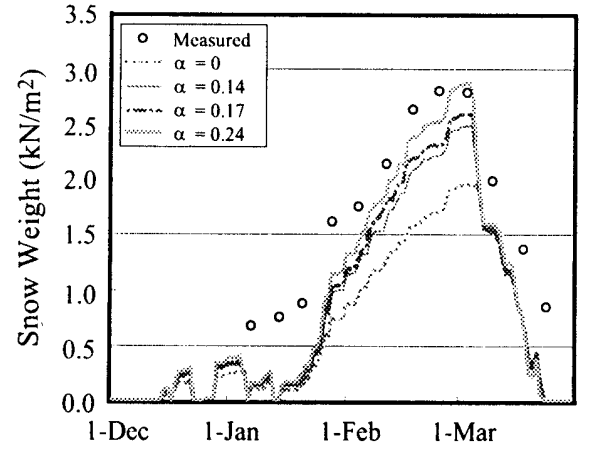

a) Sapporo 1963-1964

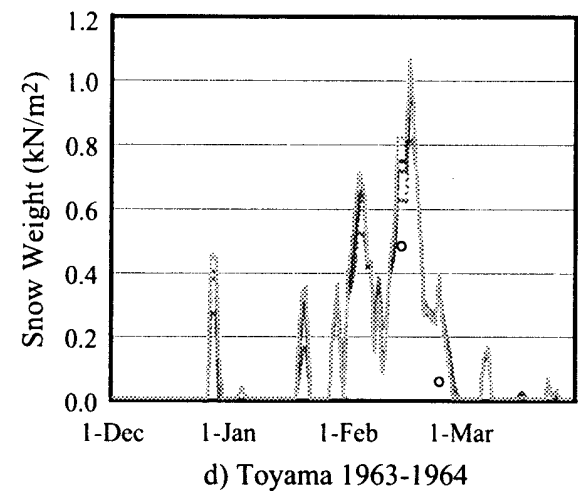



b) Shinjo 1976-1977

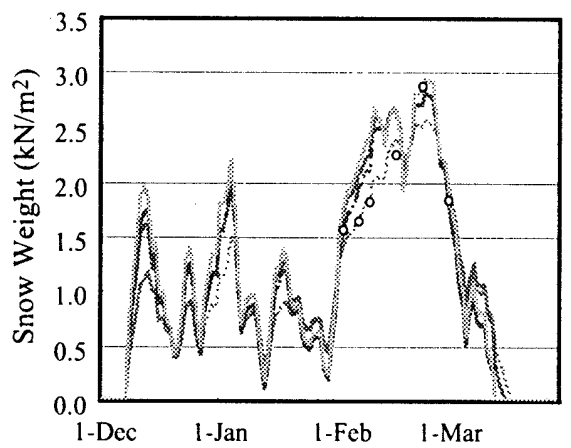

e) Toyama $1967-1968$



c) Takada 1966-1967

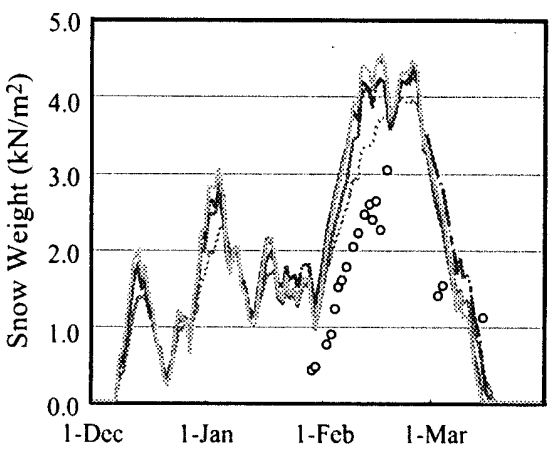

f) Fukui $1967-1968$

Figure 7. Example of measured and estimated snow weight using Ohno's catch ratio.

the present paper were collected from 1964 to 1968 for Sapporo, from 1964 to 1968 for Takada, from 1964 to 1968 for Toyama, and in 1967 \& 1968 for Fukui. An example of snow pit observation is shown in Figure 4.

Snow pit observations have been continually performed by the Science and Technology Agency, The National Research Institute for Earth Science and Disaster Prevention (NIED). Data from 1976 to 1980 in the Shinjo Branch of Snow and Ice Studies ${ }^{13)}$ were used in the present paper. The Shinjo Branch of Snow and Ice Studies used a snow sampler to perform the observation, so the water equivalent was calculated directly and used in the present paper.

The daily observed snow depth, daily mean and daily minimum air temperature of corresponding observatories belonging to the Japan Meteorological Agency are used for verification. These meteorological data are offered as SDP (Surface Daily Processing) data by the Japan Meteorological Agency. Each pit observation point is located in the same city as SDP data observed. The winter seasons used in the present paper include ordinary winter and warm winter as shown in Figure 6. The extraordinary heavy snow seasons are not included.

\subsection{Calculation method}

The calculation is done for one day step using observed daily precipitation, and daily mean and daily minimum air temperature. As mentioned in section 2, only $\rho_{\min }$ and $C_{m}$ were unknown factors in the analysis. These factors which made the following estimation error $e_{r}$ a minimum were searched using the random search method to lead to the optimum solution for the transition process of snow depths.

$$
e_{r}=\sqrt{\sum\left(d_{E}-d_{O}\right)^{2}}
$$

where, $d_{E}=$ estimated daily snow depth, and $d_{o}=$ observed daily snow depth.

The proposed snow layer model is used to calculate the snow weight transition process, using estimated coefficients $\rho_{\min }$ and $C_{m}$. The snow weight is fundamentally accumulation of cumulative precipitation. When the catch ratio is less than 1.0 , The precipitation value is divided by the catch ratio for data correction. When the daily mean air temperature is higher than $-2^{\circ} \mathrm{C}$, the weight is deducted by $W_{c}$ as expressed by Equation 7. Snowmelt is assumed to occur from the top layer down, and the overflowing water is absorbed into the next layer and percolates underground from the bottom layer when it can not be absorbed.

\subsection{Results with Ohno's catch ratio}

Figure 6 compares observed and estimated transition processes of snow depth. Regardless of Ohno's catch ratio, estimated snow depth shows a good approximation to actual values.

Figure 7 shows the snow weight transition process corresponding to winter seasons shown in Figure 6. Although the snow depth estimations show similar results, the snow weight processes show different results with regard to coefficients $\rho_{\min }$ and $C_{m}$. Generally, estimated snow weights increase as correction factor $\alpha$ increases. However, whether the correction factor gives the most appropriate estimated result of the snow weight varies from site by site.

In Sapporo, $\alpha=0.24$ seemed suitable. However, in Takada, Toyama and Fukui, $\alpha=0$ seemed better, i.e., there was no need to use a correction coefficient. This result was not compatible with Ohno's proposal. Therefore, the authors decided to find another factor that would give an efficient catch ratio. 

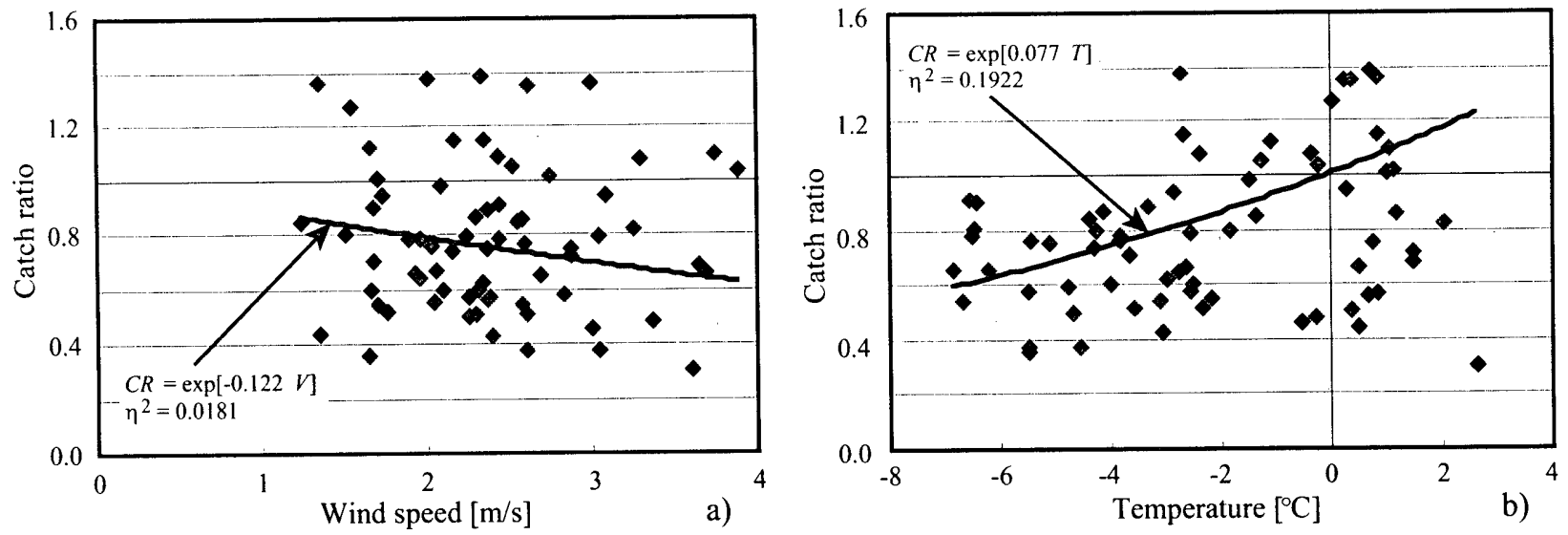

Figure 8. Relationship among windspeed, temperature and catch ratio.

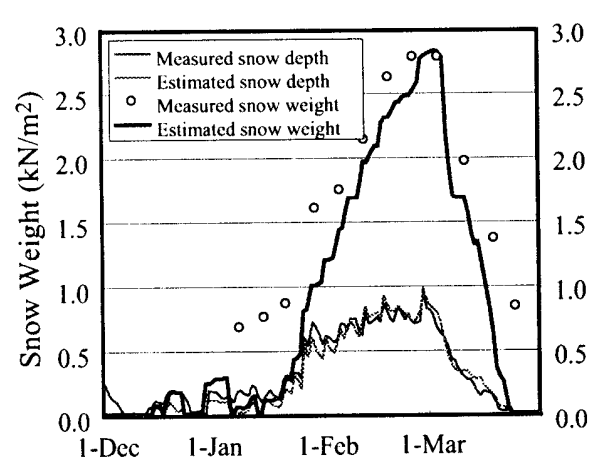

a) Sapporo $1963-1964$

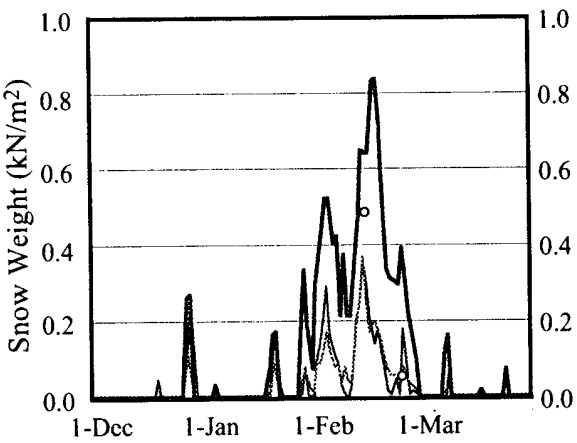

d) Toyama 1963-1964

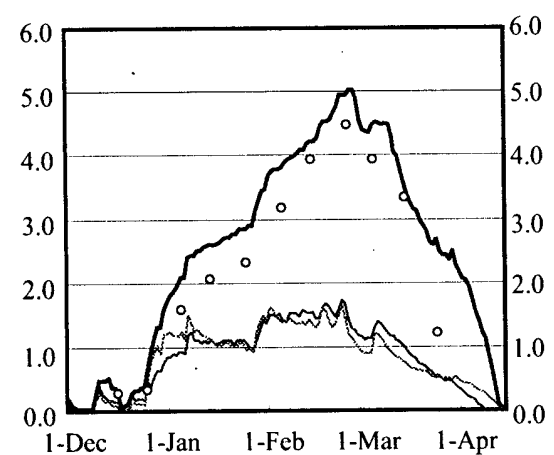

b) Shinjo 1976-1977

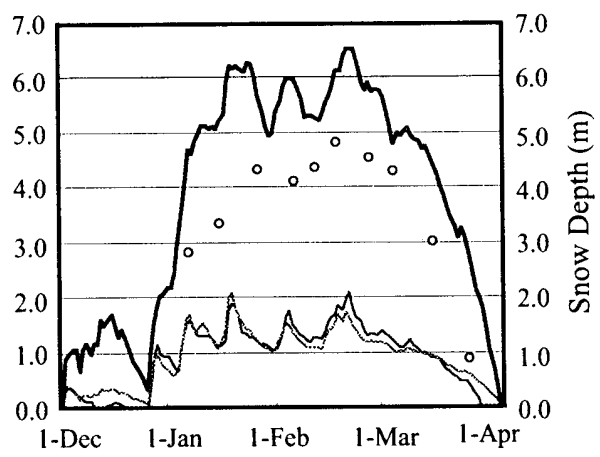

c) Takada 1966-1967

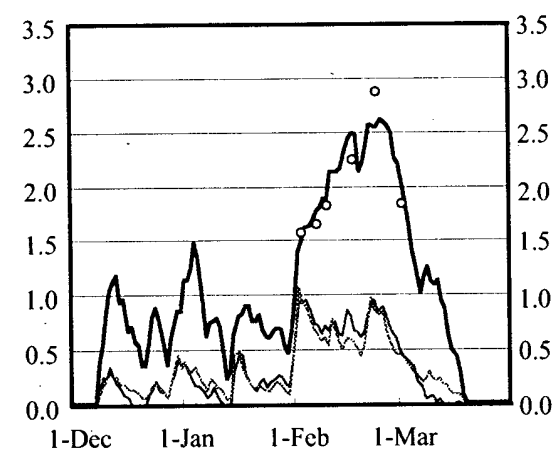

e) Toyama 1967-1968

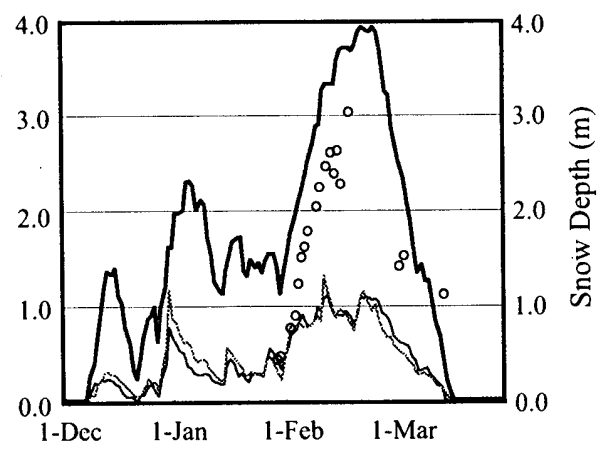

f) Fukui 1967-1968

Figure 9. Estimated snow depth and snow weight with proposed catch ratio.

\section{CONSIDERATION OF CATCH RATIO}

\subsection{Estimated catch ratio}

In considering catch ratio, the authors defined the following value as estimated catch ratio.

$$
C R=\frac{S_{P}}{S_{M}+\left(S_{P}-S_{E}\right)}
$$

where, $S_{P}=$ snow weight directly calculated from cumulative precipitation data during observation interval, $S_{M}=$ observed difference in snow weight during the observation interval, and $S_{E}=$ estimated difference in snow weight during the observation interval. Therefore, Equation 10 indicates a catch ratio considering snowmelt during the corresponding observation interval.

\subsection{Effect of wind speed and temperature}

Figure $8 \mathrm{a}$ shows the relationship between the estimated catch ratio de- fined in Equation 10 and the average daily mean wind speed during the corresponding observation interval. It is hard to see a clear relationship. Its correlation coefficient $R=-0.05$.

Figure $8 \mathrm{~b}$ shows the relationship between the estimated catch ratio and the average daily mean air temperature during the corresponding observation interval. It seems to indicate that the lower the temperature, the smaller the catch ratio. Its correlation coefficient $R=0.29$.

Therefore, the following approximation can be expressed for the catch ratio using the daily mean air temperature. The equation is assumed to yield 1.0 when the mean air temperature is higher than $0^{\circ} \mathrm{C}$.

$$
\begin{array}{ll}
C R=\exp (0.077 T) & \left(T \leq 0^{\circ} \mathrm{C}\right) \\
C R=1.0 & \left(0^{\circ} \mathrm{C}<T\right)
\end{array}
$$

The square correlation coefficient $\eta^{2}$, that is defined by Equation $12^{14)}$, 
for Equation 11a is 0.19, as shown in Figure 8b.

$$
\eta^{2}=1-\sum_{i=1}^{n}\left(y_{i}-\hat{y}_{i}\right)^{2} / \sum_{i=1}^{n}\left(y_{i}-\bar{y}\right)^{2}
$$

where, $y_{i}=$ observed value, $\hat{y}_{i}=$ estimated value, $\bar{y}=$ the mean of observed values.

\subsection{Results for proposed catch ratio}

Figure 9 compares calculation results with proposed catch ratio expressed by Equation 11. The results appear to be accurate for all observation points comparing with Figure 7. Therefore, the proposed catch ratio, as expressed by Equation 11, can be used for correction of catch ratio on precipitation gauges.

\section{CONCLUSIONS}

For quick estimation of ground snow load, the authors built a snow layer model using data of daily precipitation, daily mean and daily minimum air temperature. By using this model, we can get the estimated transition precess of both ground snow depth and ground snow load.

Although the catch ratio of solid precipitation is important for estimating the snow load on the ground, the calculation results using the catch ratio proposed by Ohno et al. were insufficient for some observation points. Therefore, the authors have proposed a new equation for the catch ratio using daily mean temperature. The results with this newly proposed catch ratio was accurate for all observation points.

For the next step of the estimation, regional characteristics of coefficients $\rho_{\min }$ and $C_{m}$ should be considered, and this will be useful for observation points without snow depth measurement.

\section{ACKNOWLEDGMENT}

The authors would like to thank the following person and organization for their kind associate: Mr. Y. Mochizuki, Graduate Students of Chiba University, for help with calculation. For the acquisition of SDP data, a grant in aid of "Development of a New Building Construction System" was obtained from the Japanese Ministry of Construction.

\section{REFERENCES}

1). Kamimura, S. \& Umemura, T.: Estimation of Daily Snow Mass on the Ground Using Air Temperature and Precipitation Data, Proc. of 2nd. International Conference on Snow Engineering, CRREL Special Report 92-27, pp.157-167, 1992.
2). Sakurai, S., Joh, O. \& Shibata. T.: Estimation of ground snow weight based on daily precipitation and daily mean air temperature, Proc. of $3 \mathrm{rd}$. International Conference on Snow Engineering, Snow Engineering, Recent Advances. Rotterdam: A.A.Balkema, pp.185-192, 1997.

3). Takahashi, H. \& Nakamura, T.: Seppyo-Bosai. Tokyo: Hakua Shobo (in Japanese), 1986.

4). Kuramoto, K., Takahashi, T.: Estimation of ground snow load using snow layer model, Part I Comparison with observed data of snow layer, Summaries of Technical Papers of Annual Meeting, Architectural Institute of Japan B-1, pp. 107-108, 1997.9.

5). Takahashi, T., Kuramoto, K.: Estimation of ground snow load using snow layer model, Part 2 Characteristics of minimum density and coefficient of melting, Summaries of Technical Papers of Annual Meeting, Architectural Institute of Japan B-1, pp.109$110,1997.9$.

6). Takahashi, T., Kawamura, T.: Estimation of ground snow load using snow layer model, Part 3 Application of the method to AMeDAS data, Proceedings of Japan Society for Snow Engineering, Vol.15, pp.75-76, 1999.2.

7). Takahashi, T., Kawamura, T.: Estimation of ground snow load using snow layer model, Part 4 Consideration for catch ratio of precipitation gauge, Summaries of Technical Papers of Annual Meeting, Architectural Institute of Japan B-1, pp.81-82, 2000.9.

8). Kinoshita, S.: Yuki no hanashi, kori no hanashi (The story of snow and ice). Tokyo: Maruzen (in Japanese), 1984.

9). Yoshida, S.: Study on snow melt, Journal of Meteorological Research, Japan Meteorological Agency, 14 (12): 879-899 (in Japanese), 1962.

10). Otoishi, S.: Estimating the value of snow-melt, Journal of Meteorological Research, Japan Meteorological Agency, 24 (12): pp.517-526 (in Japanese), 1972.

11). Ohno, H., Yokoyama, K., Kominami, Y., Inoue, S., Takami, S.\& Wiesinger, T.: Catch ratios of gauges for solid precipitation in Hokuriku region, Journal of Japanese Society of Snow and Ice, 60 (3): pp.225-231 (in Japanese with English abstract), 1998.

12). Yoshida, J.: Fundamental Research for Snow Disaster, Sapporo: Institute of Low Temperature Science, Hokkaido University (in Japanese), 121 pp., 1969.4

13). National Research Center for Disaster Prevention: Profile Investigation of Physical Properties of Snow Cover on the Ground Surface at Shinjo City During 5 Winter Periods of 1975 to 1980, Review of Research for Disaster Prevention, No.70, Tsukuba: National Research Center for Disaster Prevention, 1982

14). Takeuchi, K. (eds): Dictionary of Statistics, Toyo_Keizai_Shimposha, Tokyo, Japan, 1989. 


\section{和文要約}

1.はじめに

従来、積雪重量を直接観測した資料が限られていることから、設 計用積雪荷重の基となる地上積雪重量の推定には地上積雪深の值 に等価単位積雪重量を撕计合わせる手法が用いられてきた。一方、 気象庁の AMeDAS 観測点は全国に1,300箇所ほど存在し、1 時間毎 の降水量を自動的に記録している。積雪重量は、融雪分を除けば 基本的には降水量であるから、このデータを地上積雪重量の推定 に用いることが出来れば、より合理的な地上積雪重量の推定に とって大いに役立つことが期待できる。これまでに、上村らりや桜 井ら 2)が降水量と気温を用いて地上積雪重量を推定しているが、年 最大地上積雪重量の評価に重要となる融雪量の評価法に問題点を 残して抢り、研究の余地があると考えた。本報では、積雪層モデ ルに基づく地上積雪重量推定法を構築し、併せて降水量計の捕捉 率について検討を行った結果を報告する。

\section{2. 積雪層モデルの構築}

\section{1 積雪層 周知のように、地上積雪は一降雪毎に層を形成し} ており、層毎に密度や硬度などの物理的特性が異なっている。そ こで、本研究では 1 日の降雪が 1 つ層を形成すると仮定し、以下 のように密度と融雪過程を仮定して推定を行った。

2.2 積雪の密度 降雪時の密度は氷点下ではほぼ一定だが、気温 が $0^{\circ} \mathrm{C}$ を越えると非常にばらつくことが知られている3”。そこで、筆 者らは工学的判断により降雪時の密度を(1)式、すなわち Figure 1a に示すように仮定した。また、層毎の密度の日変化を既往の研究 ${ }^{8)}$ を基に(4)式、すなわちFigure 1bのように表されると仮定した。こ のとき降雪から $n$ 日目の積雪層の厚さは (5) 式のように表される。 ここで用いられる ${ }_{m} k$ は降雪日の密度の初期值を規定するための変数 であり、(4)式の $n$ を 0 と置けば(6)式のようになることがわかる。こ の值は、降雪日の平均気温が $0^{\circ} \mathrm{C} よ り$ 高い場合に、見かけ上Figure $1 \mathrm{~b}{ }_{m} k$ 日目から密度変化が開始されることを意味している。

\section{3 雨雪判別 日最低気温が $2^{\circ} \mathrm{C}$ 以上の日の降水は雨になると判} 断され、全降水量が表面下の層にしみ込むものと仮定している。 のようにすることにより、時として起こる箃冬期の降雨も積雪重量 の增加として評価可能となる。しみ込んだ層の密度が $500 \mathrm{~kg} / \mathrm{m}^{3}$ を超 える時は、さらにその下の層にしみ込むものとした。

2.4 融雪係数 日平均気温が $T_{0}$ よりも高い場合に、(7)式に従っ て、最も上の層から順に融雪量が $W_{C}$ になるまで融雪が起こるもの と仮定した。融雪した水は下の層に流出し、最終的には土に吸収さ れると仮定している。本研究では、日平均気温がー $2^{\circ} \mathrm{C}$ を越えると、 日中の数時間は外気温が $0^{\circ} \mathrm{C}$ を越えることもあることを考慮して、 $T_{0}=-2^{\circ} \mathrm{C}$ と仮定している。

\section{5 降水量計と捕捉率現在気象庁では主に 3 種類の降水量計} が用いられているが、大野ら“はこれらの種類ごとに、降雪時の 風速と捕捉率の関係を観測し、(8) 式のような関係式を提案してい る。補正係数 $\alpha$ は降水量計の機種によって異なる値が提案されて いるが、本研究では提案された 3 種類の倸数と補正なしの場合につ いて検討を行うこととした。

\section{3. 積雪深と積雪重量の推定}

3.1 検証に用いたデータ 本研究で推定值の検証に用いたのは 吉田らによる 1964 年から 1968 年までの積雪断面観測データ ${ }^{22)}$ と、
科学技術庁新庄雪水防災研究支所における 1976年から 1980年まで の積雪断面観測データ13)である。

3.2 計算方法 計算は1日単位で行われ、(1)式に示される一冬期 間の降雪の最小密度 $\rho_{\min }$ と、(7) 式に示される融雪係数 $C_{m}$ のつをパ ラメータとし、(9)式で示される積雪深の変化過程の推定値と実測値 の誤差が最小となるように、推定した上で、地上積雪重量変化過程 を推定した。

3.3 大野らの捕捉率に基つく結果Ｆigure6 にはこの捕捉率に基 づいて補正された降水量を用い、積雪層モデルを用いて推定され た積雪深の変化過程を示す。積雪層モデルに基づく積雪梁の推定 は捕捉率に関わらず実測值と良好な一致をみている。Figure 7には 同様に地上積雪重量の推移過程と、実測重量の推移過程の比較例を 示す。これによると、札幌ではRT-3用の補正係数を用いた方がより よい推定結果を与え、逆に高田、富山、福井では補正しない方が実 測値との整合性がよい結果となっている。紙面の都合で他の年度に ついては載せられないが、傾向は同様であり、南の地点ほど補正し ない方が良い傾向が観察され、降水量計の種類よりも地点ごとの傾 向の方が顕著であった。

\section{4. 捕捉率に関する考察}

4.1 推定捕捉率 降水量計の捕捉率と気象因子の相関を調べる 目的で、(10)式によって捕捉率を逆算して検討した。 $\left(S_{P}-S_{E}\right)$ を分母 に加えているのは、観測期日間での融雪量も考慮した捕捉率を推 定するためである。(10)式で推定された捕捉率と、観測期日間の平 均風速ならびに平均気温の関係をプロットしてみたのがFigure 8で ある。Figure 8a) より明らかなように、捕捉率と観測期日間の平均 風速の間には明確な相関関係がみられない結果となった。これらの 相関係数は-0.05であった。それに対し、Figure 8 b) によれば、 観測期日間の平均気温が低い時ほど捕捉率も低い傾向が読み取れる。 これらの相関係数は 0.29 であった。

4.2 捕捉率補正式の提案 Figure $8 \mathrm{~b})$ の結果に、日平均気温 $T=$ $0{ }^{\circ} \mathrm{C}$ で捕捉率が 1 となるように指数関数を当てはめて回帰式を求め ると(11)式のようになった。(12) 式で定義されるこの回帰式の二乗 相関係数は 0.19 であった。この捕捉率に関する回帰式を用いて補 正した降水量を用いて積雪重量を推定した結果を Figure 9 に示す。 Figure 9には積雪深の実測値と推定値の対比も併せて示した。Figure 9 の結果を Figure 7 と比較すると、Figure 9 の推定結果はいずれも Figure 7の推定において最も良好な近似結果に近い結果となってお り、(11）式の有効性を示すことができた。

5. まとめ

日本国内の約 1,300 箇所あまりで観測されている AMeDAS の降 水量データを地上積雪重量の推定に用いることを目的として、積 雪層モデルの構築を試み、過去の地上積雪重量実測データと比較 することを通じて、その検証を行った。その結果、地点によって 推定に過不足が生じるが、その傾向は既往の研究による降水量計 の種類毎の捕捉率では説明が付かないことがわかった。そこで、積 雪層モデルによる推定結果と実測積雪重量を対比させて新たな推 定捕捉率を計算して検討した結果、観測期日間の平均風速との間 には明確な関係を見いだすことはできず、平均気温と捕捉率の関 係を用いて補正することで良好な積雪重量の推定結果を得ること ができた。

(2000年10月10日原稿受理，2001年 3 月 6 日採用決定) 